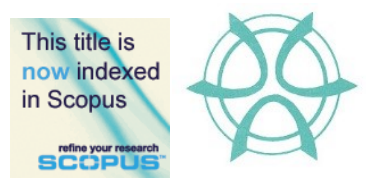

PLANNING MALAYSIA:

Journal of the Malaysian Institute of Planners

VOLUME 19 ISSUE 3 (2021), Page 23 - 36

\title{
INVESTMENT STYLES OF REIT PROPERTY PORTFOLIOS
}

\author{
Tan Chor Heng ${ }^{1} \&$ Ting Kien Hwa ${ }^{2}$ \\ ${ }^{1}$ Faculty of Built Environment, \\ TUNKU ABDUL RAHMAN UNIVERSITY COLLEGE \\ ${ }^{2}$ Faculty of Architecture, Planning \& Surveying, \\ UNIVERSITI TEKNOLOGI MARA
}

\begin{abstract}
Investment style, comprising generic-style and specific-style, is the real estate investment management approach adopted by REIT management in guiding the construction of their portfolios. These portfolios would have distinctive return and risk performance reflecting the stated risk and return underlying the investment vision. Using quantitative and qualitative approaches, this study identified the investment style of each M-REIT listed on Bursa Malaysia. Using the generic-style criteria and analysis, M-REITs are found to have pursued passive and value strategies aided by a top-down approach to their property portfolio management. Whilst results of the specific style analysis show that core portfolios have produced a lower risk-return ratio compared to value-added and opportunistic portfolios. These findings will benefit investors by guiding their investment decision making in constructing their investment portfolios and also in deciding ways to achieve diversification.
\end{abstract}

Keywords: Property portfolios, investment style, risk and return

\footnotetext{
${ }^{1}$ Undergraduate Student at Tunku Abdul Rahman University College. Email: chorheng98@gmail.com
} 
Tan Chor Heng \& Ting Kien Hwa

Investment Styles of REIT Property Portfolios

\section{INTRODUCTION}

Investing in diversified portfolios involves consideration of risk tolerance and style characteristics with an eye on systematic changes affecting investing opportunities in the overall investment landscape (Baum and Hartzell, 2012, Baum, 2015). Style is a statement of the approach adopted by a portfolio manager to real estate investment management reflecting the stated risk tolerance. According to Peyton (2008), style is usually expressed as a combination of:

a) generic style (active or passive, top down or bottom up, value or growth),

b) specific style (core, value-added or opportunistic)

This study focuses on the listed REIT sector in Bursa Malaysia. In December 2019, there are 18 listed REITs and 1 unlisted REIT in Malaysia. There are 5 Office REITs, 5 Retail REITs, 4 Mixed REITs, 2 Industrial REITs, 1 Healthcare REIT, 1 Hospitality REIT and 1 Education REIT in Malaysia.

The outcome of this research is particularly useful to retail and institutional investors, where the investment styles identified can assist them in making the right M-REIT investment decision making. Coupled with the knowledge on fundamental, technical and sentimental analysis of a particular MREIT, investors will be able to benefit by developing the most suitable investment portfolio. For retail investors, the style box helps the investors to construct a diversified portfolio that reduces overall volatility and increase expected return.

The objectives of the study are:

a) To determine the investment style of each M-REIT

b) To determine the investment styles of M-REIT in general

c) To identify the effect of investment style on the performance of M-REIT

\section{LITERATURE REVIEW}

According to Parker (2011), investment style is a clear statement of approach to property investment management to be selected by the REIT demonstrating the stated risk tolerance underlying the vision or goals of the REIT. Generally, investment style is articulated as a combination of generic style and specific style. Typically, generic style is classified into three categories, namely Active or Passive, Value or Growth, and Top-down or Bottom-up. On the other hand, specific style is divided into Core, Value-Added, and Opportunistic. This research has come up with a set of guidelines and criteria for the purpose of identifying the investment styles adopted by M-REITs. 
PLANNING MALAYSIA

Journal of the Malaysia Institute of Planners (2021)

\section{Generic Style: Active or Passive}

Active Style

The REIT manager seeks to actively manage an asset or portfolio of assets so as to add value and enhance returns above those achieved by a benchmark/index. The characteristics include but are not limited to: -

a) The real estate e.g. shopping mall is occupied by tenants from various retails, trades and services e.g. TGV Cinema, Jaya Grocer, H\&M, Padini, Haidilao, Tealive etc.

b) The manager needs to actively source tenants to occupy most spaces within the real estate, say the occupancy rate is less than $90 \%$. Thus, additional effort is required to attract tenants into the real estate.

c) Tenant turnover is expected to be significant as there is a high likelihood a tenant would move out from the real estate.

\section{Passive Style}

The REIT manager seeks to replicate or follow a benchmark in order to approximate the risk-return of the benchmark. The characteristics include but are not limited to: -

a) The real estate is occupied by single or multiple tenants which is from the same parent company with a large company size. For example: Nestle, KPJ Healthcare, DHL, Maxis and so forth. Generally, this applies to real estate such as corporate office, factories, hospitals, universities and government buildings.

b) The manager needs not to actively source tenants to occupy the spaces within the real estate as the tenants are less likely to move out from the real estate due to high investment capital for the plants and machinery.

c) The tenants have either long leases, usually more than 10 years, or a proven track record of consistent and successful tenancy or lease renewal.

\section{Generic Style: Value or Growth}

Value Style

The REIT manager focuses on real estate which are essentially mispriced, as well as offering the potential for abnormal income, capital and total returns over a predetermined future timeframe. The characteristics include but are not limited to:

a) The real estate is generally located in emerging hotspots, non-prime or secondary areas such as Shah Alam, Setapak and Subang Jaya.

b) It focuses on generating growth in rental income from its real estate.

c) Typically, it comes with an active style of management e.g., adjusting tenant mix, repositioning, rebranding etc. 
Tan Chor Heng \& Ting Kien Hwa

Investment Styles of REIT Property Portfolios

\section{Growth Style}

The REIT manager focuses on building a portfolio comprising real estate that offer the potential for growing income, capital and total returns over an undefined and usually longer future timeframe. The characteristics include but are not limited to: -

a) The real estate is generally located in prime areas such as Central Business District (CBD), Kuala Lumpur City Centre, Golden Triangle and Petaling Jaya.

b) It focuses on generating stable rental income from its real estate.

c) Typically, it comes with a passive style of management i.e., buy and hold.

\section{GENERIC STYLE: TOP-DOWN OR BOTTOM-UP}

Top-Down Approach

The REIT manager studies the global, national, regional and local real estate markets to examine the optimal geographic areas and real estate sectors for investment, then seeking assets within such areas and sectors for property acquisitions. The characteristics include but are not limited to: -

a) Market/Sector/Industry analyses are reported in the annual report of the REIT.

b) Market news or headlines can be found in the company website.

c) Specific style can be core, value-added or opportunistic.

\section{Bottom-Up Approach}

The REIT manager seeks to specifically consider the investment attributes of an individual real estate and their acceptability as the basis of acquisition. The characteristics include but are not limited to: -

a) Building attributes e.g., location, accessibility, building quality and design.

b) Surrounding neighborhood characteristics e.g., employment, amenities and facilities.

c) Specific style is usually of opportunistic as it places more emphasis on individual opportunities e.g., mispricing of property.

\section{SPECIFIC STYLE: CORE, VALUE-ADDED AND OPPORTUNISTIC}

Core Style

The REIT manager emphasizes on existing, well-leased and high-quality real estate in established and matured markets. It generally reflects stable and predictable income flows from strong credit and reputable tenants. Other characteristics include but are not limited to: -

a) The real estate is generally situated in prime areas e.g. Central Business Districts (CBD), Kuala Lumpur City Centre and Golden Triangle. 
b) It requires a relatively high proportion of total return from rental income and cash flow.

c) Capital appreciation plays a lesser role.

d) The real estate has an excellent tenant mix and tenant quality in terms of reputation, credit quality etc.

e) It records a comparatively low distribution yield due to lower risk. As a rule of thumb, the yield is less than $5 \%$ per annum.

Value-Added Style

The REIT manager seeks to increase the value of the real estate investments. Often these real estates will have sub-optimal occupancy rate, operational issues or some physical obsolescence. Hence, significant expertise and experience in retenanting and rehabilitating the assets are required (Shilling and Wurtzebach, 2012). Other characteristics include but are not limited to: -

a) The real estate is generally situated in non-prime areas such as Shah Alam, Georgetown, Johor Bahru and so forth.

b) It focuses on capital appreciation of the real estate.

c) It involves assets that require refurbishment or major enhancement resulting in repositioning.

d) The real estate has a good tenant mix and tenant quality in terms of reputation, credit quality and so forth.

e) It records a moderate yield due to moderate risk. As a rule of thumb, the yield is between $5 \%$ to $6 \%$ per annum.

Opportunistic Style

In this instance, the REIT manager is willing to take entrepreneurial risk in order to achieve out-sized returns by investing into real estate from ground up development, adaptive reuse, to emerging markets. Other characteristics include but are not limited to: -

a) The real estate is generally situated in suburban or outskirt areas such as Sepang, Kajang, Ipoh, Seremban and Malacca. Overseas properties are also in this category.

b) The real estate has a fair tenant mix and tenant quality in terms of reputation, credit quality and so forth.

c) It records a relatively high distribution yield due to higher risk. As a rule of thumb, the yield is more than $6 \%$ per annum. 
Tan Chor Heng \& Ting Kien Hwa

Investment Styles of REIT Property Portfolios

\section{RESEARCH METHODOLOGY}

Introduction

This section highlights the research methodology to examine the investment style of each individual Malaysia REIT, as well as the effect of specific investment style on the REIT performance.

\section{Research Process}

The total return of each REIT is calculated based on the average changes of monthly closing price and the income distribution of the respective REIT, which are annualised to arrive at its annual return.

Risk refers to the chance an outcome or investment's actual gains will differ from an expected outcome or return. To quantify risk, the standard deviation of the monthly returns is used to measure the volatility of a REIT and are annualised to obtain its annual risk.

Property portfolio information and data of the M-REITs are collected from 2018 annual reports. The information collected include name of property, type of property, size, acquisition date, purchase price, latest valuation and date of valuation, location, age etc. By combining the data collected with the sets of criteria for each investment style, the investment style adopted to manage each property is identified.

In addition, the monthly closing price since the IPO listings of each REIT listed in Malaysia is obtained, without any adjustment to any capital changes such as rights and bonus issues. Furthermore, any distribution by the respective REIT is also recorded in the month of its ex-date.

\section{ANALYSIS OF RESULTS \\ Investment Styles of REITs in Malaysia}

Generic Style: Active or Passive

Two-thirds of the properties owned by M-REITs are managed passively by the managers. Most of these properties, regardless of their types, are located in established areas such as Golden Triangle and Petaling Jaya. There are 145 properties being managed passively, as opposed to 73 properties being managed actively by REIT managers. 


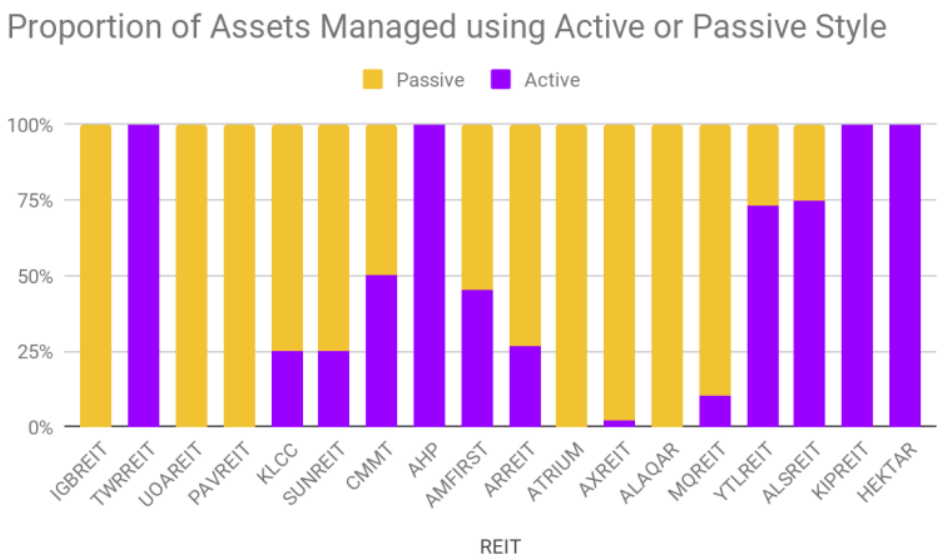

Figure 1: Breakdown of active and passive style properties

Figure 1 shows there are 4 REITs which fully manage their assets actively, namely AHP, HEKTAR, KIPREIT, and TWRREIT. The major characteristics of these REITs are that the real estate is located in non-prime areas (in the case of HEKTAR and KIPREIT) and tenant movement within the real estate is expected to be frequent (in the case of AHP and TWRREIT). Moreover, REITs like ALSREIT and YTLREIT actively manage most of their properties due to the nature of business which is in the food \& beverage sector (i.e. ALSREIT) and hospitality sector (i.e. YTLREIT), where active management is required to ensure the stability and sustainability of the operation.

On the other hand, there are 6 REITs which passively manage all of their assets, namely ALAQAR, ATRIUM, AXREIT, IGBREIT, PAVREIT, and UOAREIT. The main characteristics of these REITs are that the assets are located in prime areas (in the case of IGBREIT, PAVREIT and UOAREIT) or tenant movement is expected to be less frequent due to the nature of business which mainly associated with industrial and hospital (in the case of ALAQAR, ATRIUM and AXREIT). Besides, REITs like ARREIT, KLCC, MQREIT and SUNREIT passively manage most of their assets, with a minority of them being managed actively so as to achieve higher return on investment.

Lastly, there are 2 REITs which manage their assets both actively and passively, namely AMFIRST and CMMT. These REITs owns and operates real estate which are situated in both prime and non-prime locations. In this category, the real estate is expected to generate growing return for the REIT as some risks are taken, with the establishment of a certain margin of safety. 
Tan Chor Heng \& Ting Kien Hwa

Investment Styles of REIT Property Portfolios

\section{Generic Style: Value or Growth}

Two-thirds of the properties owned and operated by M-REITs are managed with the goal of enhancing the value of the assets; while one-third of the properties are managed with the goal of embracing growth of the assets. This result is mostly similar to the above-mentioned "Generic Style: Active or Passive", where the value style is aligned with passive style (144 properties); while the growth style is aligned with active style ( 74 properties).

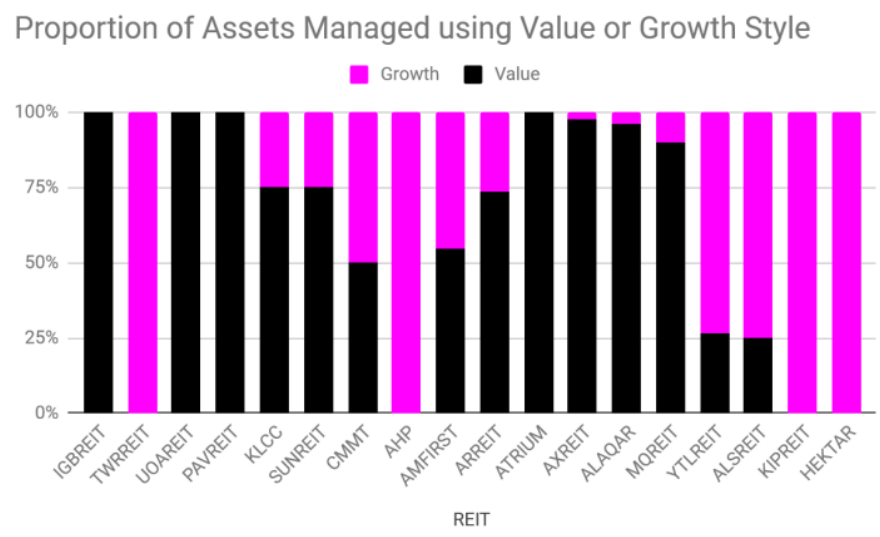

Figure 2: Breakdown of growth and value style properties

Based on Figure 2, there are 4 REITs which completely practice growth style in managing their assets, namely AHP, HEKTAR, KIPREIT and TWRREIT. Similar to the active style of management, the major characteristics of these REITs are that the real estate are located in non-prime, but growing areas such as Subang Jaya and Johor Bahru. Moreover, REITs like ALSREIT and YTLREIT also practice growth style in managing most of their properties due to the nature of business which is in the food \& beverage sector (in the case of ALSREIT) and hospitality sector (in the case of YTLREIT), where active management is required to ensure the stability and sustainability of the operation. In return, the REITs are expecting significant appreciation in their capital so as to compensate their efforts and risks in managing these assets.

On the contrary, there are 6 REITs which practice value style in managing their assets, namely ALAQAR, ATRIUM, AXREIT, IGBREIT, PAVREIT, and UOAREIT. The main characteristics of these REITs are that the assets are located in prime areas. Besides, value style of management is also reflected in REITs like ARREIT, KLCC, MQREIT and SUNREIT so as to achieve constant returns from the properties in the form of rental income, resulting in consistent and positive cash flow being generated. Lastly, AMFIRST and CMMT are seen to practice both value and growth style when managing their 
portfolio of assets, where they own and operate real estate which are situated in both prime and non-prime locations. In this category, the real estate is expected to generate both capital appreciation and rental income for the REITs.

\section{Generic Style: Top-Down or Bottom-Up}

In Malaysia, 151 out of 218 properties (69.3\%) owned and operated by REITs are invested with the practice of top-down style to determine the market opportunity and risk when making management decisions. In contrast, 67 out of 218 properties $(30.7 \%)$ are invested with the practice of bottom-up style to consider the investment attributes of an individual real estate and their acceptability as the basis of acquisition.

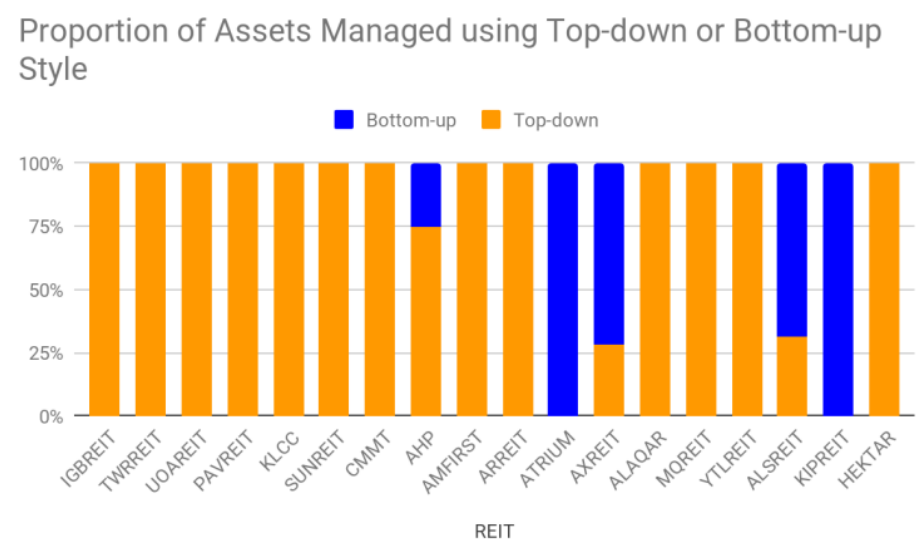

Figure 3: Breakdown of top-down and bottom-up style properties

Figure 3 shows that there are 13 REITs which fully practice top-down approach to examine market opportunity and risk when making management decisions, namely ALAQAR, AMFIRST, ARREIT, CMMT, HEKTAR, IGBREIT, KLCC, MQREIT, PAVREIT, SUNREIT, TWRREIT, UOAREIT, and YTLREIT. Detailed market/sector/industry analysis prepared by either professional property consultants and/or the management itself are found in the annual reports of these REITs. Besides, $75 \%$ of the assets (3 out of 4 properties) of AHP adopts the topdown approach when making investment or management decision.

On another note, bottom-up approach is practiced by 2 REITs, namely ATRIUM and KIPREIT, where the REIT manager seeks to specifically consider the investment aspects of an individual property and their acceptability as the basis of acquisition. Market/sector/industry analysis are absent in the annual report of these REITs. This is followed by ALSREIT and AXREIT, where the REIT managers practice bottom-up approach for the majority of their portfolio when making management decisions. 
Tan Chor Heng \& Ting Kien Hwa

Investment Styles of REIT Property Portfolios

\section{Specific Style: Core, Value-Added or Opportunistic}

In Malaysia, most of the properties (40.4\%) are managed with opportunistic style, followed by core style (33.5\%) and value-added style (26.1\%). AXREIT, ALSREIT and ALAQAR contribute approximately $57 \%$ of the total number of properties managed under opportunistic style; AXREIT and ALSREIT contribute $49 \%$ of the total number of properties managed under value-added style; SUNREIT and AXREIT contribute $30 \%$ of the total number of properties managed under core style. However, this statistic is greatly influenced by AXREIT, ALSREIT and ALAQAR as they own and operate a large number of properties, which comprise approximately $47 \%$ of the total number of properties owned and operated by REITs in the country.

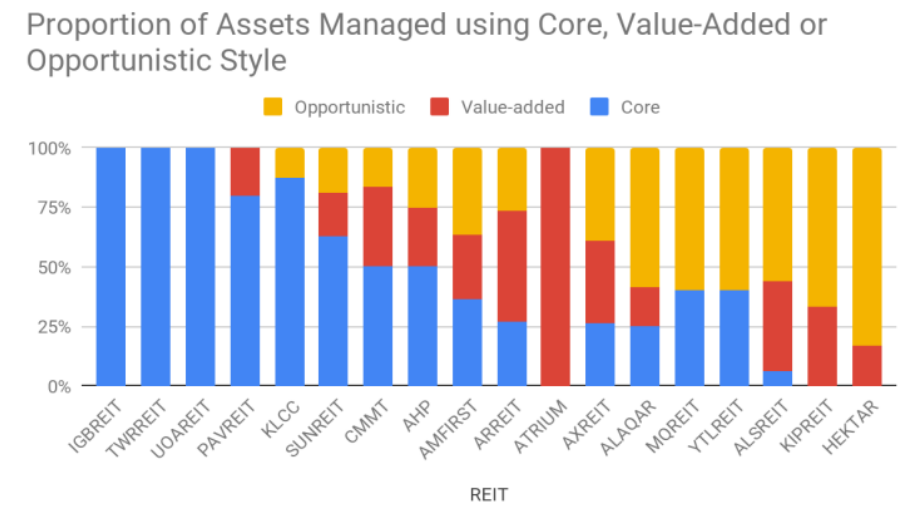

Figure 4: Breakdown of core, value-added and opportunistic style properties

Based on Figure 4, IGBREIT, TWRREIT and UOAREIT manage all of their assets using core style; while ATRIUM adopts value-added style to manage all of their properties. Other REITs that adopt core style include PAVREIT, KLCC and SUNREIT, where the real estate of these REITs is located in prime area or Central Business Districts (CBD) such as Bukit Bintang, Kuala Lumpur City Centre and Damansara. Excellent mix and quality of tenants are also a key similarity between these properties, resulting in a lower distribution yield due to lower risk. The excellent mix and quality of tenants are not only due to the strong management capability, but also due to the attractive and prime address that the properties are located at, resulting in higher quality tenants are interested to lease spaces within the real estate.

Furthermore, other REITs that use value-added style include CMMT, AHP, AMFIRST, ARREIT and AXREIT. The main similarities between these REITs are that capital appreciation is the focus. Besides, the situation of the properties managed by these REITs are mainly in non-prime locations such as 
PLANNING MALAYSIA

Journal of the Malaysia Institute of Planners (2021)

Shah Alam, Cyberjaya and Subang Jaya. In addition, some of the buildings require refurbishment or major enhancement before or after the acquisition of properties. Some examples include Sungei Wang Plaza, Summit Subang and HELP University Jalan Semantan. Due to the moderate level of risk involved, moderate distribution yield of $5-6 \%$ is required.

Lastly, REITs practicing opportunistic style are ALAQAR, MQREIT, YTLREIT, ALSREIT, KIPREIT and HEKTAR. In this instance, certain degree of entrepreneurial risk is taken, where the REITs are investing in ground up developments or real estate that require redevelopment and adaptive reuse. Generally, this asset class includes vacant land, properties located in overseas locations, non-conventional properties, as well as properties located in suburban or outskirts. Some examples include KPJ International College, Sydney Harbour Marriott, Segamat Central, and a parcel of vacant land with the Lot No. 173, Seksyen 58, Town of Kuala Lumpur. However, due to the relatively poor location, these properties appear to be less attractive in the eyes of quality tenants, thus having a fair mix and quality of tenants within the real estate. As a result, higher distribution yield is needed to compensate for the higher risk taken by the investors.

\section{PERFORMANCE OF REITS IN MALAYSIA}

Since the introduction of Bursa Malaysia REIT Index on 2 October 2017, the index has recorded a $3.25 \%$ decline from $1,015.11$ to 982.10 as at 29 November 2019. Although such decline may develop a discouraging perception towards REITs in Malaysia, the index is only 2 years old and does not have sufficient time series data to prove the long-term performance of the asset class. Regardless, the real estate asset class will appreciate in the long run due to its inflation hedging characteristic and growing population in Malaysia.

In this research paper, the effects of specific investment styles on the performance of Malaysia REITs was studied. A summary of performance of Malaysia REITs in relation to the respective specific investment style is depicted in Figure 5. 
Tan Chor Heng \& Ting Kien Hwa

Investment Styles of REIT Property Portfolios

Performance of M-REITs in Relation to Specific Investment Styles

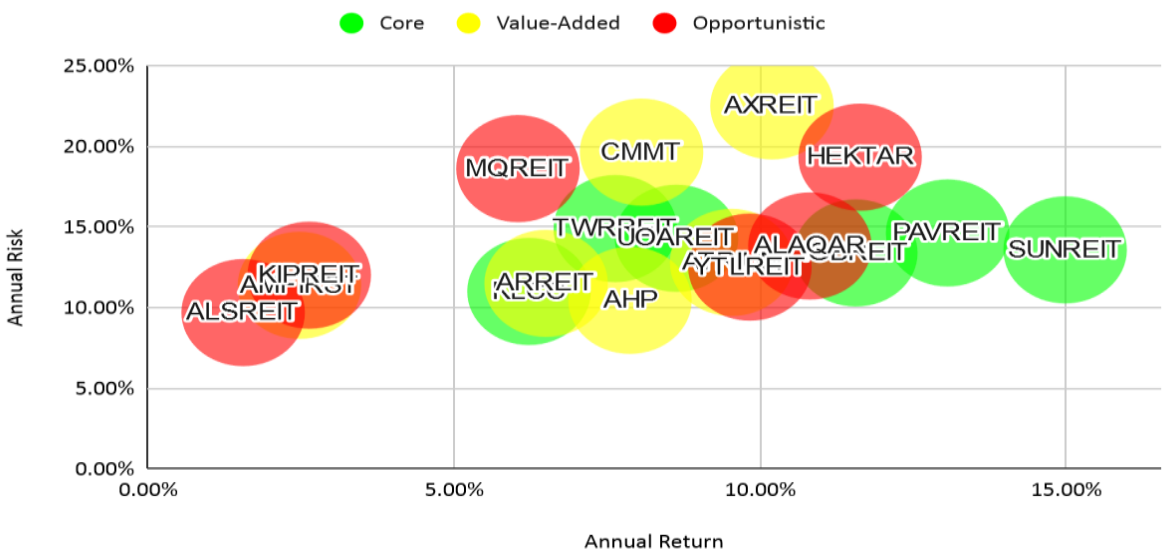

Figure 5: Performance of M-REITs in relation to specific investment styles (January 2006 to November 2019)

The annual risk of M-REITs range between $9.70 \%$ and $22.52 \%$ for the study period from January 2006 to November 2019; while its annual return ranges from $1.55 \%$ to $14.98 \%$. In other words, the risks of investing in REITs in Malaysia is higher than its returns. A summary of the performance of each REIT is highlighted in Table 1.

Table 1: Risk and return of M-REITs (January 2006 - November 2019)

\begin{tabular}{|c|c|c|c|c|c|}
\hline & $\begin{array}{l}\text { Investment } \\
\text { styles }\end{array}$ & $\begin{array}{c}\text { Annual } \\
\text { Return } \\
(\%)\end{array}$ & $\begin{array}{c}\text { Annual } \\
\text { Risk } \\
(\%)\end{array}$ & $\begin{array}{l}\text { Risk/Return } \\
\text { ratio }\end{array}$ & $\begin{array}{c}\text { Average } \\
\text { Risk/Return } \\
\text { ratio }\end{array}$ \\
\hline IGBREIT & Core & $11.56 \%$ & $13.40 \%$ & 1.1592 & \multirow{6}{*}{1.4283} \\
\hline TWRREIT & Core & $7.63 \%$ & $14.91 \%$ & 1.9541 & \\
\hline UOAREIT & Core & $8.63 \%$ & $14.31 \%$ & 1.6582 & \\
\hline PAVREIT & Core & $13.06 \%$ & $14.64 \%$ & 1.1210 & \\
\hline KLCC & Core & $6.22 \%$ & $11.01 \%$ & 1.7701 & \\
\hline SUNREIT & Core & $14.98 \%$ & $13.59 \%$ & 0.9072 & \\
\hline CMMT & Value-Added & $8.06 \%$ & $19.65 \%$ & 2.4380 & \\
\hline AHP & Value-Added & $7.87 \%$ & $10.46 \%$ & 1.3291 & \\
\hline
\end{tabular}


PLANNING MALAYSIA

Journal of the Malaysia Institute of Planners (2021)

\begin{tabular}{|c|c|c|c|c|c|}
\hline AMFIRST & Value-Added & $2.47 \%$ & $11.39 \%$ & 4.6113 & \multirow{4}{*}{2.2839} \\
\hline ARREIT & Value-Added & $6.50 \%$ & $11.51 \%$ & 1.7708 & \\
\hline ATRIUM & Value-Added & $9.53 \%$ & $12.81 \%$ & 1.3442 & \\
\hline AXREIT & Value-Added & $10.19 \%$ & $22.52 \%$ & 2.2100 & \\
\hline ALAQAR & Opportunistic & $10.81 \%$ & $13.83 \%$ & 1.2794 & \multirow{6}{*}{3.0215} \\
\hline ALSREIT & Opportunistic & $1.55 \%$ & $9.70 \%$ & 6.2581 & \\
\hline HEKTAR & Opportunistic & $11.63 \%$ & $19.34 \%$ & 1.6629 & \\
\hline KIPREIT & Opportunistic & $2.63 \%$ & $12.02 \%$ & 4.5703 & \\
\hline MQREIT & Opportunistic & $6.04 \%$ & $18.63 \%$ & 3.0844 & \\
\hline YTLREIT & Opportunistic & $9.83 \%$ & $12.52 \%$ & 1.2737 & \\
\hline
\end{tabular}

Overall, SUNREIT which has the lowest risk-return ratio was the best performer for the study period. On the other hand, ALSREIT has the worst performance and is the most volatile REIT among others, with a relatively low return accompanied by moderate risk. The average risk/return ratio of Core style REITs is 1.4283 , followed by Value-added REITs at 2.2839, and Opportunistic Style REITs at 3.0215. The relative risk/return for these three investment styles is consistent with the investment adage - high risk high return and low risk low return.

Generally, the lower the risk/return ratio, the less volatile is the REIT. In the Core category, IGBREIT, PAVREIT and SUNREIT records a lower calculated risk/return than the average risk/return, indicating their capability in maintaining a greater stability among other REITs within the same category. Besides, in the Value-Added category, CMMT and AMFIRST records an above average calculated risk/return, representing their inability to maintain a lower volatility than the industry standards. Lastly, in the Opportunistic category, ALAQAR, HEKTAR and YTLREIT records a lower calculated risk/return than the average risk/return, indicating their ability to maintain a greater stability than their competitors in the industry.

\section{CONCLUSION}

In a nutshell, the results of our research reveal that most of the real estate portfolios are managed passively by the REIT managers to generate consistent rental income relying on long term leases. Besides, the value approach is adopted by majority of the REIT managers to achieve a greater potential of income or 
Tan Chor Heng \& Ting Kien Hwa

Investment Styles of REIT Property Portfolios

return. Furthermore, more than two-thirds of the REIT managers practice topdown style to determine market opportunity and risk when making investment management decisions. Moreover, most REIT managers apply core style in managing their individual assets by focusing on existing, well-leased and highquality properties in established key property sectors and prime locations.

Last but not least, the results of our research have been aligned with our hypothesis, where the Core style represents low risk, low return; while the Opportunistic style represents high risk, high return. For retail and institutional investors, the identified investment style portfolios of M-REITs give them the flexibility to choose from an array of investment portfolios that meet their investment mandates. If the investor is more conservative and risk averse, he might want to invest into REITs which practice Core investment style such as SUNREIT, PAVREIT, IGBREIT, TWRREIT, UOAREIT and KLCC. For an investor who has moderate tolerance towards risk, REITs under the Value-added category such as CMMT, AHP, AMFIRST, ARREIT, ATRIUM and AXREIT would be a suitable choice. Lastly, aggressive investors who are willing to take up more risk to bet for a better potential return can invest into REITs adopting Opportunistic investment styles such as ALAQAR, ALSREIT, HEKTAR, KIPREIT, MQREIT and YTLREIT.

\section{REFERENCES}

Baum, A. E. (2015). Real estate investment: a strategic approach. London: Routledge Taylor \& Francis Group.

Baum, A. E. and Hartzell, D. (2012) Global Property Investment: Strategies, Structures, Decisions, John Wiley \& Sons

Chuweni, N. N., \& Eves, C. (2019). Measuring Technical Efficiency of Malaysian Real Estate Investment Trusts: A Data Envelopment Analysis Approach, Planning Malaysia Journal of the Malaysian Institute of Planners, Vol. 17 Issue 1, 319-327

Garay, U. (2016) "Investment Styles, Portfolio Allocation, and Real Estate Derivatives." In Kazemi, H.; Black, K.; and D. Chambers (Editors), Alternative Investments: CAIA Level II, Chapter 16, Wiley Finance, 3rd Edition, 2016, pp. 401-421.

Parker, D. (2011). Global real estate investment trusts: people, process and management. Chichester, West Sussex: Wiley-Blackwell.

Peyton, M. S. (2008). Real Estate Investment Style and Style Purity, Journal of Real Estate Portfolio Management, Vol. 14 No. 4, 325-334

Shilling, J. D. and Wurtzebach, Charles H. (2012). Is Value-Added and Opportunistic Real Estate Investing Beneficial? If So, Why? Journal of Real Estate Research, Vol. 34 No. 4, 429-461 